\title{
Analysis of superficial mycoses in children examined in 2013-2016 in the Unit of Medical Mycology at the Department of Dermatology, Poznan University of Medical Sciences
}

\author{
Analiza przypadków występowania grzybic powierzchownych u dzieci badanych \\ w Pracowni Mikologii Lekarskiej Katedry i Kliniki Dermatologii Uniwersytetu \\ Medycznego w Poznaniu w latach 2013-2016
}

Anna Browicz', Honorata Kubisiak-Rzepczyk', Marta Hasse-Cieślińska', Aneta Karasińska², Zygmunt Adamski'

'Department of Dermatology, Poznan University of Medical Sciences, Poland

2Department of Dermatology, The Nicolas Copernicus State Hospital, Koszalin, Poland

'Katedra i Klinika Dermatologii Uniwersytetu Medycznego im. Karola Marcinkowskiego w Poznaniu, Polska

2Oddział Dermatologii Szpitala Wojewódzkiego im. Mikołaja Kopernika w Koszalinie, Polska

CORRESPONDING AUTHOR/ ADRES DO KORESPONDENCJI:

lek. Anna Browicz

Katedra i Klinika Dermatologii

Uniwersytet Medyczny

im. Karola Marcinkowskiego

ul. Przybyszewskiego 49

60-356 Poznań

tel.: +48722389617

e-mail: annabrowicz@gmail.com

\begin{abstract}
Introduction. The superficial mycoses remain a group of diseases of public health significance. The increased incidence of mycoses is related, among other factors, to deficiency of the immune system, coexisting systemic and dermatological diseases, long-term, non-target antibiotic therapy and the increase in the number of people at risk of immunosuppression.

Objective. To analyze the etiology and epidemiology of mycosis in patients under 18 years of age in the years 2013-2016 diagnosed in the Unit of Medical Mycology at the Department of Dermatology, Poznan University of Medical Sciences.
\end{abstract}

Material and methods. A retrospective, etiological and epidemiological analysis was performed on the incidence of superficial mycosis in 295 patients under 18 years of age diagnosed in the years 2013-2016 in the Unit of Medical Mycology at the Department of Dermatology, Poznan University of Medical Sciences.

Results. The study group included mostly cases of dermatophytic superficial mycosis of the scalp with prevalent zoophilic species, including Microsporum canis as the most common.

Conclusions. Superficial mycoses are common during childhood. Increased incidence of certain forms of superficial mycoses in children has been observed, for example infections transmitted from exotic animals or onychomycosis.

\section{STRESZCZENIE}

Wprowadzenie. Zachorowania na powierzchowne grzybice mają ciągle duże znaczenie dla zdrowia publicznego. Zwiększona częstość występowania grzybic wiąże się m.in. z niedoborami immunologicznymi, współistniejącymi chorobami układowymi i dermatologicznymi, 
długotrwałą niecelowaną antybiotykoterapią i wzrostem liczby ludzi zagrożonych immunosupresją.

Cel pracy. Analiza etiologii i epidemiologii grzybicy u pacjentów poniżej 18. roku życia w latach 2013-2016 diagnozowanych w Pracowni Mikologii Lekarskiej Katedry i Kliniki Dermatologii Uniwersytetu Medycznego w Poznaniu.

Materiał i metodyka. Przeprowadzono retrospektywną analizę etiologii i epidemiologii grzybicy powierzchownej u 295 pacjentów poniżej 18. roku życia diagnozowanych w latach 2013-2016 w Pracowni Mikologii Lekarskiej Katedry i Kliniki Dermatologii Uniwersytetu Medycznego w Poznaniu.

Wyniki. W badanej grupie pacjentów najczęściej występowała powierzchowna grzybica dermatofitowa skóry owłosionej głowy. Przeważały gatunki zoofilne, a wśród nich Microsporum canis.

Wnioski. Grzybice powierzchowne stanowią częsty problem w populacji dziecięcej. Obserwuje się zwiększoną częstość zachorowań na szczególne postaci grzybic, np. pochodzących od zwierząt egzotycznych czy grzybicę paznokci.

Key words: superficial mycoses, fungal infections, children, dermatophytes, epidemiology.

Słowa kluczowe: grzybice powierzchowne, zakażenia grzybicze, dzieci, dermatofity, epidemiologia.

\section{INTRODUCTION}

Mycosis is a frequently diagnosed skin disease in children [1]. The number of new cases of fungal infections in the youngest patients is steadily increasing [2]. The most important human pathogenic fungi include dermatophytes, yeast-like fungi and mold fungi. Fungi are opportunistic pathogens, which under normal homeostasis of the body do not pose any threat. Some of them are a part of the natural saprophytic flora of the skin and mucous membranes, while others are found in the natural human environment. However, there are a number of causative factors for initiating fungal infections in children. Diagnostic tests of children for fungal infection should focus on factors that promote the formation of a fungal infection [1-3]. The development of infection with yeast-like and mold-like fungi is particularly affected by immune deficiencies as well as local conditions of the skin and mucous membranes [4]. The increasing number of chemotherapeutic and immunosuppressive therapies used in patients under 18 years of age has a particular impact on the development of these infections [4]. The susceptibility of children to superficial fungal infections results, among other things, from an impaired cellular immune response and decreased counts of Langerhans cells and NK cells, as well as numerous adverse reactions resulting from the toxic effects of

\section{WPROWADZENIE}

Grzybica jest chorobą skóry często rozpoznawaną u dzieci [1]. Liczba nowych przypadków zakażeń grzybiczych u najmłodszych pacjentów stale wzrasta [2]. Głównymi grzybami patogennymi u ludzi są dermatofity, grzyby drożdżopodobne i pleśniowe. Grzyby są patogenami oportunistycznymi, które w warunkach homeostazy organizmu nie stwarzają żadnego zagrożenia dla człowieka. Niektóre z nich wchodzą w skład naturalnej flory saprofitycznej skóry i błon śluzowych, a inne występują w normalnym środowisku życia ludzi. Istnieje kilka czynników wywołujących zakażenia grzybicze u dzieci. Badania diagnostyczne u dzieci w kierunku zakażenia grzybiczego powinny skupiać się na czynnikach sprzyjających powstawaniu takich zakażeń [1-3]. W rozwoju zakażeń grzybami drożdżopodobnymi i pleśniowymi istotną rolę odgrywają zwłaszcza niedobory odporności, a także miejscowy stan skóry i błon śluzowych [4]. Do powstawania zakażeń przyczynia się coraz częstsze stosowanie chemioterapii i leczenia immunosupresyjnego u pacjentów poniżej 18 lat [4]. Za zwiększoną podatność dzieci na grzybice powierzchowne odpowiada m.in. osłabienie komórkowej odpowiedzi immunologicznej, a także zmniejszenie liczby komórek Langerhansa i komórek NK oraz liczne reakcje niepożądane wynikające $z$ toksycznego oddziaływania leków immunosupresyjnych na narządy (nefrotoksyczność, nadczynność i efekt 
immunosuppressants on the organs (nephrotoxicity, hyperactivity and diabetogenic effects). There is also a change in the quality of the stratum corneum, which promotes the spread of fungal infection [5]. It also seems unreasonable to use intensive, long-lasting antibiotic therapy [2]. Immunosuppression in patients increases the risk of dermatophytic infections and worsens their course, but most children with dermatophyte fungi do not have immune dysfunction. Patients with a well-functioning immune system develop dermatophyte infections as a result of environmental factors, e.g. contact with an infected animal [6].

\section{OBJECTIVE}

The objective of the study was to analyze the etiology and epidemiology of mycosis in patients under 18 years of age in the years 2013-2016, diagnosed in the Department of Mycology at the Department of Dermatology, Poznan University of Medical Sciences.

\section{MATERIAL AND METHODS}

Two hundred and ninety-five children, 75 of whom obtained positive results for fungal infection (36 girls and 39 boys) were examined. The study was carried out in the period of 2013-2016 in the Department of Mycology of the Department of Dermatology, Poznan University of Medical Sciences. A retrospective, etiological and epidemiological analysis was performed.

The research material included:

- fragments of epidermis taken from skin lesions suspected of mycosis. Samples were taken with a scalpel or surgical spoon;

- fragments of finger and/or toe nail plates, suspected of fungal infection, were collected with nippers, scissors or a surgical spoon;

- material from swabs from morphologically diseased nailfolds, and the "thread test";

- hair collected with forceps from the central part of the lesion;

- swabs of skin folds and mucous membranes.

The type of material collected depended on the clinical symptoms presented by the patient. Mycological diagnostics was performed according to the procedures of the Department of Mycology at the Department of Dermatology, Poznan University of Medical Sciences.

Each time, a fluorescence test of skin lesions on glabrous and hairy skin was performed in the light of Wood's lamp.

Another diagnostic step was a direct examination to evaluate the elements of the fungal structure. Direct microscopic examination of scales, hair and nail diabetogenny). Obserwuje się również niekorzystną zmianę stanu warstwy rogowej naskórka (stratum corneum), która sprzyja rozprzestrzenianiu się zakażeń grzybiczych [5]. Kolejnym czynnikiem jest nieuzasadnione stosowanie długotrwałej intensywnej antybiotykoterapii [2]. Immunosupresja nie tylko nasila ryzyko zakażeń dermatofitami, lecz także pogarsza ich przebieg. U większości dzieci z zakażeniem grzybami dermatofitowymi nie stwierdza się upośledzenia czynności układu immunologicznego. U pacjentów z prawidłowo funkcjonującym układem odpornościowym podłożem zakażeń dermatofitowych są czynniki środowiskowe, np. kontakt z zakażonym zwierzęciem [6].

\section{CEL PRACY}

Celem pracy była analiza etiologii i epidemiologii grzybicy u pacjentów poniżej 18. roku życia diagnozowanych w Pracowni Mikologii Lekarskiej Katedry i Kliniki Dermatologii Uniwersytetu Medycznego w Poznaniu w latach 2013-2016.

\section{MATERIAŁ I METODYKA}

W badaniu wzięło udział łącznie 295 pacjentów pediatrycznych, wśród których zakażenie grzybicze potwierdzono u 75 (36 dziewczynek i 39 chłopców). Badanie wykonano w Pracowni Mikologii Lekarskiej Katedry i Kliniki Dermatologii Uniwersytetu Medycznego w Poznaniu w latach 2013-2016. Przeprowadzono retrospektywną analizę etiologiczną i epidemiologiczną.

Analizowany materiał obejmował:

- fragmenty naskórka pobrane za pomocą skalpela lub łyżeczki chirurgicznej ze zmian skórnych, w których podejrzewano rozwój grzybicy,

- fragmenty płytek paznokciowych palców dłoni i/lub stóp, w których podejrzewano rozwój grzybicy, pobrane przy użyciu cążków, nożyczek lub łyżeczki chirurgicznej,

- materiał wymazowy pobrany z wałów paznokciowych objętych morfologicznymi zmianami chorobowymi i uzyskany w tzw. teście z przynętą nitkową,

- włosy pobrane kleszczami medycznymi ze środkowej części zmiany chorobowej,

- materiał wymazowy z fałdów skórnych i błon śluzowych.

Rodzaj pobranego materiału zależał od objawów klinicznych występujących u danego pacjenta. Diagnostykę mykologiczną przeprowadzono zgodnie z procedurami obowiązującymi w Pracowni Mikologii Lekarskiej w Poznaniu.

W każdym przypadku wykonywano test fluorescencyjny skóry gładkiej i owłosionej w świetle lampy Wooda.

Kolejnym etapem diagnostyki było badanie bezpośrednie w celu oceny elementów struktury grzyba. 
changed by disease was done by applying the material to a basic slide, subjected to a solution of $40 \%$ dimethylsulfoxide with $10-20 \% \mathrm{KOH}$ and protected with a cover slide. In the case of swabs, the material was Gram stained or lactophenol cotton blue stained with methylene blue.

The prepared preparations were subjected to microscopic evaluation at a 200 - or 400-fold magnification.

Direct examination with a microscopic assessment of the material allows for the detection of fungal elements such as hyphae or spores.

Cultures were created in order to identify species of fungi. Agar (SDA, Sabouraud dextrose agar) and SDA with actidione were used as the media to grow dermatophyte fungi.

Dermatophytic fungi culturing was conducted for a minimum of 3 weeks. Culturing of mold fungi was carried out for 14 days, and yeast-like fungi for 10-14 days $[3,7]$.

The species identification of dermatophytes and molds cultured on media was carried out on the basis of macroscopic and microscopic features of the obtained culture (picture of the hyphae and spores). In the case of yeast-like fungi, biochemical tests were performed, which evaluated the enzymatic activity of fungi and carbohydrate auxanography and nitrogen compounds.

\section{RESULTS}

The results are shown in Figures 1-5.

Forty-nine $(65.3 \%)$ cases were dermatophytic infections, $17(22.7 \%)$ cases were yeast-like infections, and $9(12 \%)$ were mold fungi infections (Fig. 4).

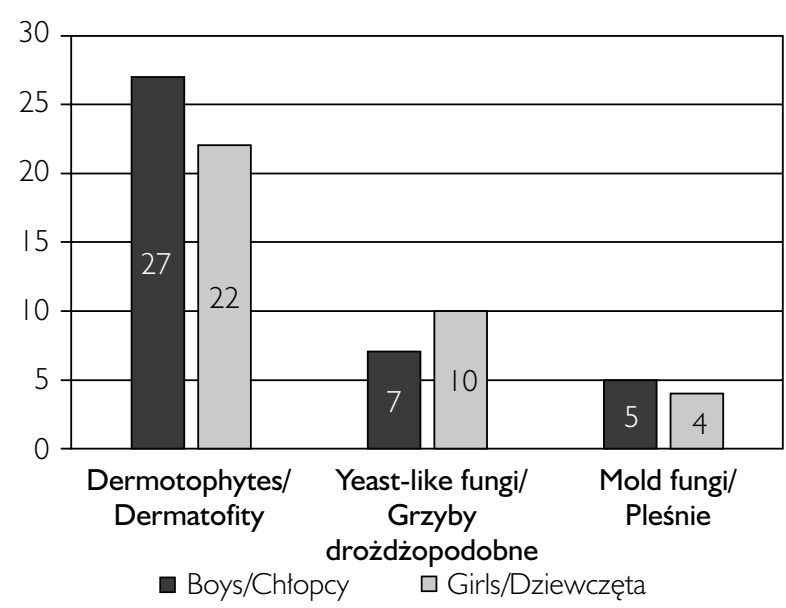

Figure I. The incidence of various types of superficial mycoses in children according to sex

Rycina I. Częstość mystępowania poszczególnych grzybic powierzchownych u dzieci według płci
Bezpośrednie badanie mikroskopowe zmienionych chorobowo łusek, włosów i paznokci wykonywano poprzez umieszczenie badanego materiału na szkiełku podstawowym, naniesienie 40-procentowego roztworu dimetylosulfotlenku z 10-20-procentowym roztworem $\mathrm{KOH}$ oraz nakrycie szkiełkiem nakrywkowym. Materiał wymazowy barwiono metodą Grama lub błękitem laktofenolowym bawełnianym z błękitem metylenowym.

Przygotowane preparaty analizowano mikroskopowo pod 200-400-krotnym powiększeniem.

Badanie bezpośrednie polegające na ocenie mikroskopowej pobranego materiału umożliwia wykrywanie takich elementów budowy grzyba, jak strzępki czy zarodniki.

W celu identyfikacji gatunkowej założono hodowle grzybów. Jako podłoże do hodowli dermatofitów wykorzystano pożywkę agarową (SDA, agar dekstrozowy Sabouraud) i SDA z aktidionem.

Hodowlę grzybów dermatofitowych prowadzono przez minimum 3 tygodnie. Hodowlę grzybów pleśniowych prowadzono przez 14 dni, a drożdżopodobnych przez 10-14 dni [3, 7].

Identyfikację gatunkową dermatofitów i pleśni wyhodowanych na podłożach wykonano na podstawie cech makro- i mikroskopowych widocznych w otrzymanych kulturach (obrazu strzępków i zarodników). W przypadku grzybów drożdżopodobnych przeprowadzono badania biochemiczne analizujące aktywność enzymatyczną grzybów oraz auksanografię z wykorzystaniem węglowodanów i związków azotowych.

\section{WYNIKI}

Wyniki przedstawiono na rycinach 1-5.

W $49(65,3 \%)$ przypadkach stwierdzono zakażenia dermatofitowe, w 17 (22,7\%) przypadkach - zakaże-

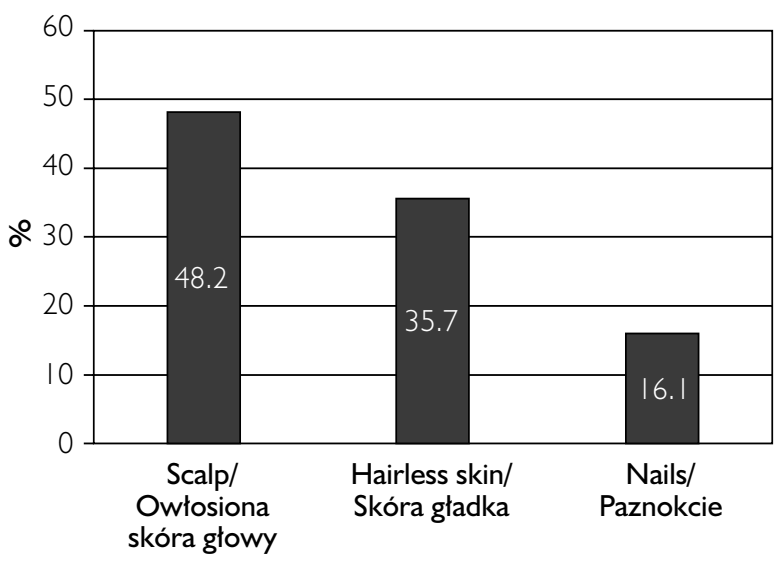

Figure 2. The incidence of dermatophytic mycosis in individual locations in the study group

Rycina 2. Częstość mystępowania grzybicy dermatofitowej w poszczególnych lokalizacjach w grupie badanej 


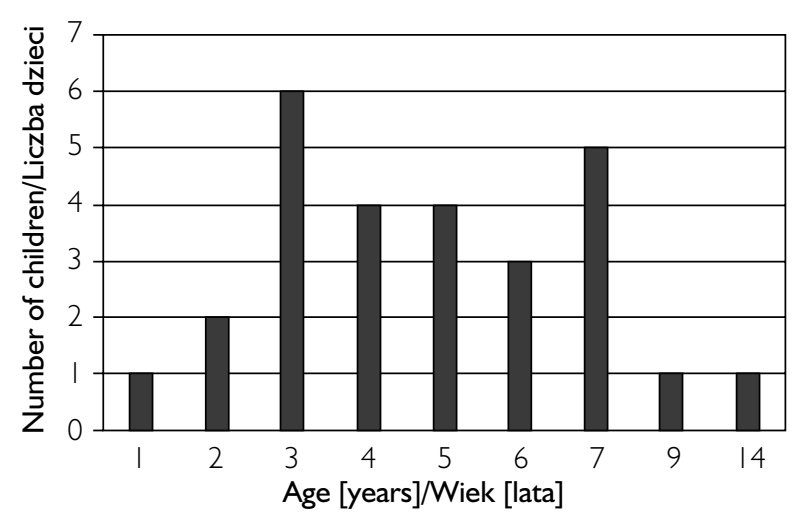

Figure 3. Number of children with dermatophytic mycosis of the scalp depending on age

Rycina 3. Liczba dzieci z grzybica dermatofitowq owtosionej skóry glowy według wieku

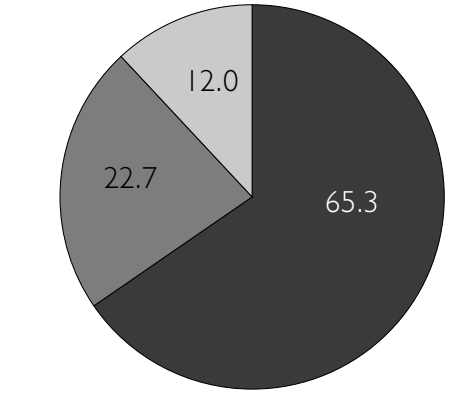

口 Dermotophytes/Dermatofity $\square$ Yeast-like fungi/Grzyby drożdżopodobne $\square$ Mold fungi/Pleśnie

Figure 4. Groups of isolated pathogenic fungi that cause superficial mycoses in the test material

Rycina 4. Grupy wyizolowanych grzybów patogennych wywołujq̨cych grzybice powierzchowne w materiale badanym

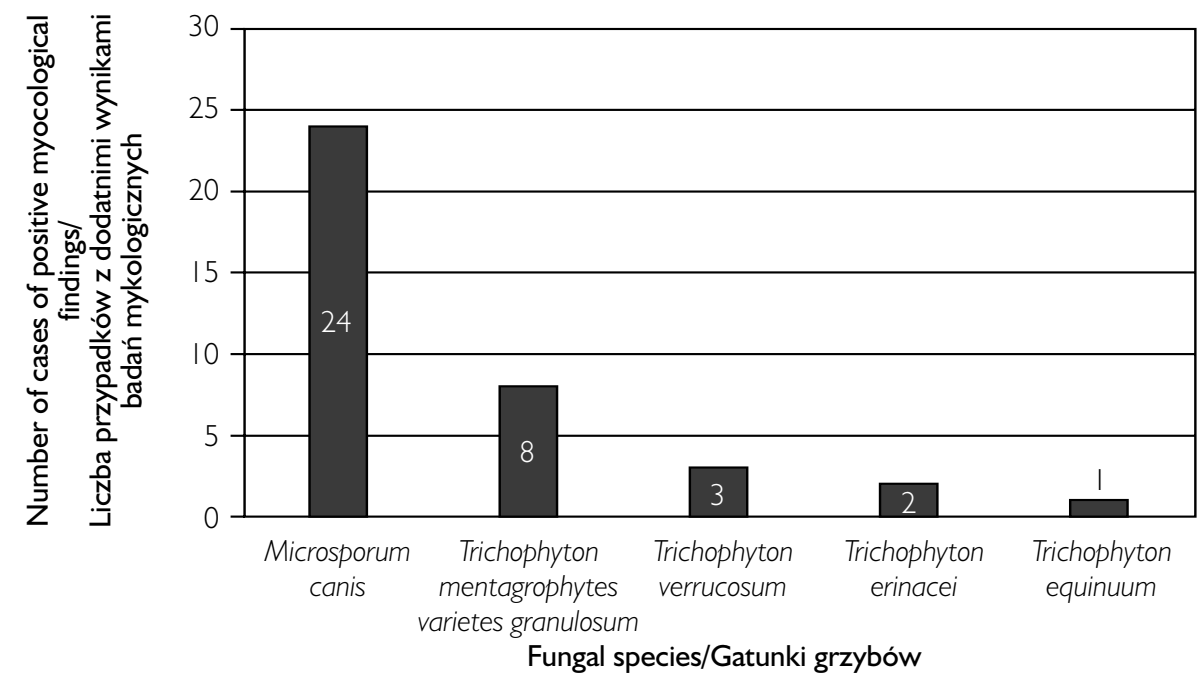

Figure 5. Zoophilic fungi isolated from diseased places

Rycina 5. Grzyby zoofilne myizolowane z miejsc zajętych choroba

\section{Dermatophytes}

Forty-nine cases of dermatophytic infections included 38 (77.6\%) zoophilic, 10 (20.4\%) anthropophilic and $1(2.0 \%)$ geophilic fungi. According to data presented in Figure 5, Microsporum (M.) canis dominated in the group of 38 cases of infections caused by zoophilic dermatophytic fungi (63.2\%).

Trichophyton (T.) mentagrophytes var. granulosum was the second most common type (21.0\%). Three (7.9\%) infections with $T$. verrucosum, $2(5.3 \%)$ with T. erinacei, and $1(2.6 \%)$ infection with T. equinuum were diagnosed.

Ten cases of anthropophilic dermatophytic fungal infections included: $40 \%$ of cases caused by T. mentagrophytes var. interdigitale, $40 \%$ by T. rubrum, and $10 \%$ of infections respectively by $T$. tonsurans and M. audouinii. nia grzybami drożdżopodobnymi, a w 9 (12\%) przypadkach - zakażenia grzybami pleśniowymi (ryc. 4).

\section{Dermatofity}

Wśród 49 przypadków zakażeń grzybami dermatofitowymi stwierdzono 38 (77,6\%) zakażeń grzybami zoofilnymi, $10(20,4 \%)$ zakażeń grzybami antropofilnymi i $1(2,0 \%)$ zakażenie grzybami geofilnymi. Zgodnie $\mathrm{z}$ danymi z ryciny 5 głównym gatunkiem wśród 38 przypadków zakażeń wywołanymi zoofilnymi grzybami dermafitowymi był Microsporum (M.) canis $(63,2 \%)$.

Drugim pod względem częstości występowania gatunkiem był Trichophyton (T.) mentagrophytes var. granulosum $(21,0 \%)$. Rozpoznano 3 (7,9\%) zakażenia gatunkiem T. verrucosum, 2 (5,3\%) zakażenia gatunkiem T. erinacei oraz $1(2,6 \%)$ zakażenie grzybem z gatunku T. equinuum. 


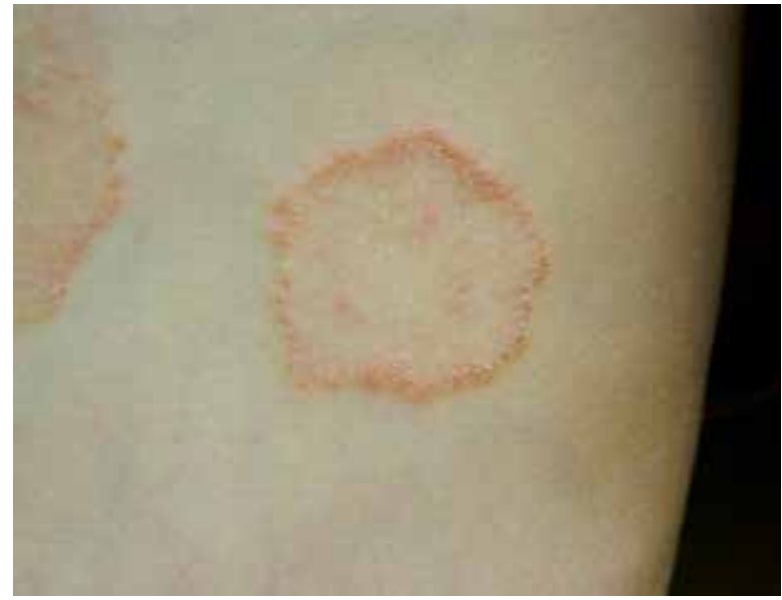

Figure 6. Trichophyton erinacei-induced lesion in the forearm skin of a child

Rycina 6. Zmiana skórna wywołana przez Trichophyton erinacei na przedramieniu dziecka

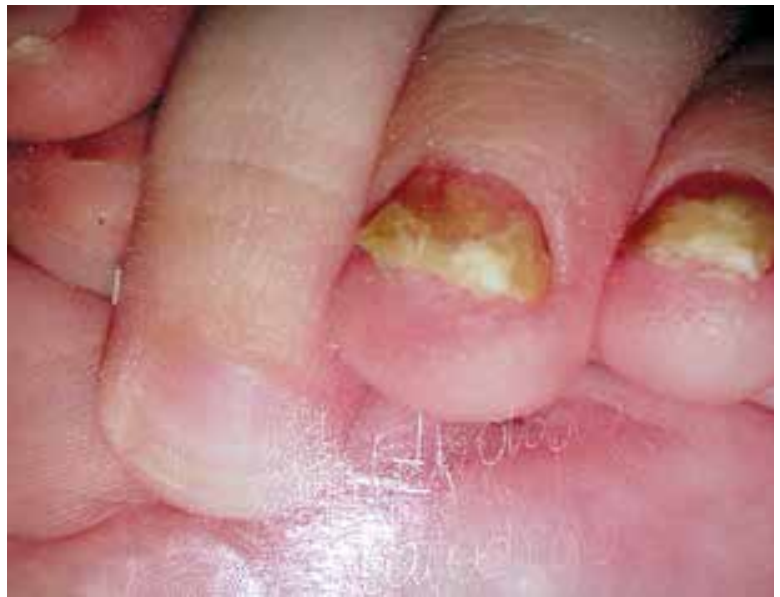

Figure 7. Fungal infection of fingernail in a 3-month-old boy

Rycina 7. Zakażenie grzybicze paznokcia ręki u 3-miesięcznego chtopca

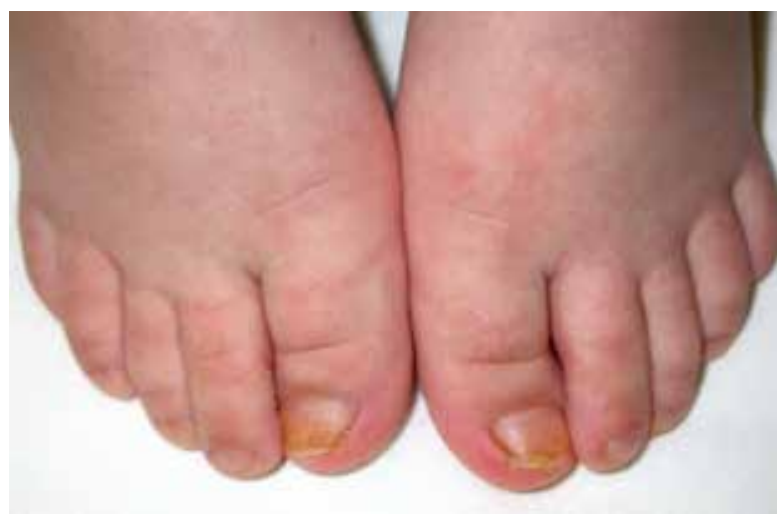

Figure 8. Fungal infection of toenail caused by Trichophyton rubrum in 5-year-old boy

Rycina 8. Zakażenie grzybicze paznokcia stopy wywołane przez Trichophyton rubrum u 5-letniego chtopca

Only 1 case of infection with geophilic fungi of the species M. gypseum was diagnosed in the study group.

In the study group, dermatophytic infection was located on the scalp in $55 \%$ of patients. Zoophilic M. canis was the most common (74.1\%) species of dermatophytic fungi occupying this location.

The second most common location occupied by dermatophytes was glabrous skin. In 20 cases, $9(45 \%)$ were caused by infection with $M$. canis and $6(30 \%)$ by T. mentagrophytes var. granulosum. Three $(15 \%)$ cases of $T$. verrucosum infection with data suggesting transmission of infection from calves were reported. In 1 patient anthropophilic M. audouinii was cultured and in another one T. erinacei. The last species was cultured from the forearm and chest of a 14-year-old patient (Fig. 6).

The Unit of Medical Mycology at the Department of Dermatology, Poznan University of Medical Sciences, in the years 2013-2016 reported 9 cases of
Wśród 10 przypadków zakażeń antropofilnymi grzybami dermatofitowymi stwierdzono $40 \%$ zakażeń wywołanych przez gatunek T. mentagrophytes var. interdigitale, $40 \%$ przez T. rubrum oraz $10 \%$ zakażeń grzybami T. tonsurans i $M$. audouinii.

W badaniu stwierdzono tylko 1 przypadek zakażenia grzybem geofilnym z gatunku M. gypseum.

U 55\% pacjentów zakażenia dermatofitowe były umiejscowione na owłosionej skórze głowy. Najczęstszym w tej lokalizacji grzybem dermatofitowym był zoofilny gatunek $M$. canis $(74,1 \%)$.

Kolejną najbardziej powszechną lokalizacją zakażeń dermatofitami była skóra gładka. Spośród 20 przypadków w 9 (45\%) stwierdzono zakażenie gatunkiem M. canis, a $6(30 \%)$ gatunkiem T. mentagrophytes var. granulosum. Odnotowano 3 (15\%) przypadki zakażenia $T$. verrucosum, przy czym zgromadzone dane wskazywały na przeniesienie zakażenia od cieląt. U 1 pacjenta wyhodowano antropofilny gatunek M. audouinii, a u innego - T. erinacei. Drugi z wymie- 
dermatophytic infections in toe- and fingernails of children aged 7 to 14 years (Figs. 7, 8). Four $(44.4 \%$ ) cases were related to $T$. mentagrophytes var. interdigitale, $4(44.4 \%)$ were related to T. rubrum, and $1(11.1 \%)$ to T. tonsurans. All cases were foot infections. Only a 13-year-old patient had T. mentagrophytes var. interdigitale coexisting with fingernail infection.

\section{Yeast-like fungi}

Yeast-like fungal infections were diagnosed in 17 patients.

Candida albicans (7 cases, $41.2 \%)$, C. parapsilosis (3 cases, $17.6 \%$ ), C. glabrata (4 cases, $23.5 \%$ ) and C. krusei (2 cases, $11.8 \%$ ) were the most common species cultured among all the cases of yeast-like fungal infections. In 2 cases the pathogenic fungus was described as Candida spp. There were 10 cases of onychomycosis (58.8\% of all yeast-like infections). In 8 patients, lesions affected the fingernails and in 2 toenails. In the study group, $70 \%$ of nail infections were diagnosed in girls and 30\% in boys. The average age of patients with nail candidiasis in the study group of children was 11 years. The youngest child was 4 years old, and the oldest was 17 years old.

Our study, in most cases, verified coexisting causative agents of infection, such as psoriasis, nail injury, previous antibiotic therapy, nail biting habit, staphylococcal and Pseudomonas bacteria superinfection, as well as acrylic nail application in young girls.

\section{Mold fungi}

Mold fungi are rarely found in mycological examination. Mold flora was confirmed in material from 9 patients. Aspergillus and Alternaria species were most frequently cultured $(33.3 \%$ and $22.2 \%$ respectively). In 4 patients, mold flora was cultured from the material of the nail or nail fold swab. Three patients demonstrated lesions of glabrous skin. A single case of Scedosporium apiospermum was reported in a surgical wound in a 17-year-old surgical patient following a largescale traumatic brain injury. A single positive result was obtained for the presence of Aspergillus fungus in the intraoperative material of the scalp area. The youngest child with confirmed flora was 20 months old and the lesions included glabrous skin of the buttock.

\section{DISCUSSION}

Between 2013 and 2016, 75 cases of superficial fungal infections were diagnosed in patients under nionych gatunków wyhodowano z materiału pobranego z przedramienia i klatki piersiowej 14-letniego pacjenta (ryc. 6).

W latach 2013-2016 w Pracowni Mikologii Lekarskiej w Poznaniu stwierdzono 9 przypadków zakażeń paznokci stóp i dłoni dermatofitami u dzieci w wieku 7-14 lat (ryc. 7,8$)$. Spośród nich $4(44,4 \%)$ zakażenia były wywołane przez T. mentagrophytes var. interdigitale, kolejne $4(44,4 \%)$ przez T. rubrum, a $1(11,1 \%)$ przez T. tonsurans. We wszystkich przypadkach zakażeniem objęte były paznokcie stóp. Tylko u 13-letniego pacjenta rozpoznano zakażenie T. mentagrophytes var. interdigitale współistniejące z zakażeniem paznokci dłoni.

\section{Grzyby drożdżopodobne}

Zakażenie grzybami drożdżopodobnymi rozpoznano u 17 pacjentów.

W przypadku zakażeń grzybami drożdżopodobnymi najczęściej hodowano: Candida albicans (7 przypadków; 41,2\%), C. parapsilosis (3 przypadki; 17,6\%), C. glabrata (4 przypadki; $23,5 \%$ ) i C. krusei (2 przypadki; 11,8\%). W 2 przypadkach zakażenie było wywołane grzybem z rodzaju Candida spp. Stwierdzono 10 przypadków grzybicy paznokci (58,8\% wszystkich zakażeń grzybami drożdżopodobnymi). W 8 przypadkach zmiany obejmowały paznokcie dłoni, a w 2 przypadkach - paznokcie stóp. W grupie 70\% zakażeń paznokci stwierdzano u dziewczynek, a 30\% u chłopców. Średni wiek pacjentów z kandydozą paznokci wynosił 11 lat. Najmłodsze dziecko miało 4 lata, a najstarsze 17 lat.

W większości przypadków badanie potwierdziło współistnienie czynników sprzyjających zakażeniu, takich jak łuszczyca, uszkodzenie paznokci, wcześniejsza antybiotykoterapia, nawyk obgryzania paznokci, nadkażenie bakteriami Pseudomonas oraz przedłużanie paznokci techniką akrylową u dziewczynek.

\section{Grzyby pleśniowe}

Grzyby pleśniowe są rzadko wykrywane w badaniach mykologicznych. Obecność flory pleśniowej potwierdzono w materiale pobranym od 9 pacjentów. Najczęściej hodowano gatunki Aspergillus i Alternaria (odpowiednio w 33,3\% i 22,2\% przypadków). U 4 pacjentów florę pleśniową wyhodowano z wyma$\mathrm{zu}$ pobranego z paznokcia lub wału paznokciowego. U 3 pacjentów występowały zmiany w obrębie skóry gładkiej. Pojedynczy przypadek zakażenia Scedosporium apiospermum stwierdzono u 17-letniego pacjenta $\mathrm{w}$ ranie po operacji z powodu rozległego urazowego uszkodzenia mózgu. Pojedynczy wynik potwierdzający obecność grzyba Aspergillus otrzymano w materiale pobranym śródoperacyjnie z owłosionej skóry głowy. Najmłodsze dziecko, u którego wykryto florę pleśniową, miało 20 miesięcy, a zmiany obejmowały skórę gładką w obrębie pośladka. 
18 years of age at the Unit of Medical Mycology at the Department of Dermatology, Poznan University of Medical Sciences. Dermatophytes were the most common group of fungi $(65.3 \%)$. This result is consistent with epidemiological reports from other regions of the country and from abroad [1,8,9]. Children are mostly infected with zoophilic dermatophytes, while adults are most frequently diagnosed with anthropophilic lesions $[1,10]$.

In the studied group of children, infection with dermatophytes was mainly located on the scalp. This location is characteristic for dermatophytic infections in children, but it also affects adults [6]. In the study group of patients, all cases of tinea capitis were caused by dermatophytes. In other reports, tinea capitis is a typical dermatological problem in patients between 3 and 7 years of age. It is rarely diagnosed in children under 2 years of age [11, 12]. The results of studies conducted in the Unit of Medical Mycology at the Department of Dermatology, Poznan University of Medical Sciences in the years 2013-2016 confirm that the most common period of mycosis is the age between 3 and 7 years. It should be noted that $11 \%$ ( 3 children) of all cases in the study group are patients under 3 years of age. According to literature reports, the actual incidence of dermatophytic mycosis in children under 3 years of age is greater than previously reported [13]. There is a need for detailed differential diagnosis of the presented symptoms such as alopecia, hair thinning, pruritus and chronic flaking of scalp resistant to antibiotic therapy and antifungal therapy [13].

The most frequent finding $(74.1 \%)$ was that of $M$. canis, the most common etiologic agent of scalp microsporiasis in children [8]. Cats are the main source of $M$. canis [14]. The oldest child who was diagnosed with $M$. canis on the scalp was 14 years old. According to various sources, the probable cause of this infection in pre-pubertal children is a reduced level of intermediate chain of fatty acids in the lipid barrier of the skin $[9,15]$. In the study group, $M$. canis infection was confirmed in 13 boys and 11 girls. According to reports, sex is not a risk factor for mycosis caused by M. canis in children. However, in the group of patients over 16 years of age it has been found to have a significant influence on the incidence of microsporiasis in girls of $3: 1$ to $6: 1$ in boys [14].

Symptoms of $M$. canis involve numerous circular foci, mainly located in the temporal and occipital areas. Microscopic examination is characterized by small spores covering the hair follicle forming the image of ectothrix, causing the hair to break a few millimeters above the skin. A mild inflammatory reaction and exfoliation may occur in the focal area [4].

\section{OMÓWIENIE}

Od 2013 do 2016 r. w Pracowni Mikologii Lekarskiej w Poznaniu rozpoznano łącznie 75 przypadków grzybicy powierzchownej u pacjentów poniżej 18 lat. Najczęstszą grupą grzybów (65,3\%) były dermatofity. Wynik ten jest zgodny z raportami epidemiologicznymi z innych regionów Polski oraz z piśmiennictwem zagranicznym $[1,8,9]$. U dzieci zwykle występują zakażenia dermatofitami zoofilnymi, natomiast u osób dorosłych zazwyczaj rozpoznaje się zmiany wywołane przez gatunki antropofilne $[1,10]$.

U dzieci zakażenia grzybami dermatofitowymi stwierdzano przede wszystkim w obrębie owłosionej skóry głowy. Lokalizacja ta jest charakterystyczna dla zakażeń dermatofitowych u dzieci, choć zdarza się także u dorosłych [6]. Wszystkie rozpoznane w badaniu przypadki tinea capitis były wywołane przez dermatofity. Według innych doniesień tinea capitis jest typowym schorzeniem dermatologicznym u pacjentów w wieku od 3 do 7 lat. Jest natomiast rzadko rozpoznawana u dzieci poniżej 2 lat $[11,12]$. Wyniki badań przeprowadzonych w Pracowni Mikologii Lekarskiej w Poznaniu w latach 2013-2016 potwierdzają, że grzybica najczęściej występuje w wieku od 3 do 7 lat. Należy zaznaczyć, że $11 \%$ wszystkich przypadków (tj. 3 dzieci) w grupie stanowili pacjenci poniżej 3 lat. Zgodnie $z$ doniesieniami częstość występowania grzybicy wywoływanej przez dermatofity u dzieci w wieku poniżej 3 lat jest wyższa, niż wcześniej przyjmowano [13]. Konieczna jest szczegółowa diagnostyka różnicowa obserwowanych takich objawów, jak łysienie, rzednięcie włosów, świąd, przewlekłe łuszczenie owłosionej skóry głowy, opornych na leczenie antybiotykowe i przeciwgrzybicze [13].

Najczęściej (74,1\%) stwierdzano obecność M. canis, najbardziej pospolitego czynnika etiologicznego grzybicy drobnozarodnikowej (microsporiasis) owłosionej skóry głowy u dzieci [8]. Głównym rezerwuarem zakażeń M. canis są koty [14]. Najstarsze dziecko, u którego rozpoznano to zakażenie w obrębie skóry owłosionej głowy, miało 14 lat. Według różnych źródeł prawdopodobną przyczyną tego zakażenia u dzieci przed okresem dojrzewania jest obniżone stężenie kwasów tłuszczowych o średnim łańcuchu węglowym w skórnej barierze lipidowej $[9,15]$. W badanej grupie zakażenie M. canis potwierdzono u 13 chłopców i 11 dziewczynek. Według doniesień płeć nie stanowi czynnika ryzyka rozwoju grzybicy wywołanej przez $M$. canis u dzieci. U pacjentów powyżej 16 lat stwierdzono jednak istotny wpływ płci na częstość występowania grzybicy drobnozarodnikowej, która jest bardziej rozpowszechniona u dziewczynek niż u chłopców (w stosunku od $3: 1$ do $6: 1)$ [14].

Objawy M. canis obejmują liczne, okrągłe zmiany zlokalizowane głównie w obszarach skroniowych i potylicznych. W badaniu mikroskopowym widoczne są 
There was also a single case of the zoophilic T. equinum infection, the most commonly present on horses, and the geophilic M. gypseum in the examined group of children.

The second most common location occupied by dermatophytes was glabrous skin of the whole body. Forty-five percent of cases were caused by infection with $M$. canis and $30 \%$ by T. mentagrophytes var. granulosum. Three $(15 \%)$ cases of T. verrucosum infection with data suggesting transmission of infection from calves were reported. Another rare fungus that was obtained in culture in 1 patient was the anthropophilic $M$. audouinii, similar to $M$. canis, but differing in microconidia.

Particular attention should be paid to the case of rare mycosis of glabrous skin, an infection caused by $T$. erinacei. It was cultured from the forearm and chest of a 14-year-old patient (Fig. 6). T. erinacei is a zoophilic fungus and the hedgehog is its natural reservoir. They have recently become breeding animals. Dermatophytes, which are natural flora of small mammals, do not induce lesions in them, which promotes the transmission of infection [16]. However, in our patient, on the basis of the interview, direct contact with a breeding hedgehog was excluded. After a thorough analysis, the girl's guinea pig was found to be the source of the infection, as it was the vector between the pet store hedgehog and the person. After 3 weeks, lesions developed on the skin of the guinea pig too.

Symptoms of fungal infections of the glabrous skin usually include annular erythematous and exfoliative lesions with skin unchanged in the center of efflorescence, and raised, inflammatory lesions in which follicular lesions are possible. In some infections, there are additionally skin lesions such as pustules and scabs, and perceptible persistent itching [1]. In the case of patients of the Unit of Medical Mycology of the Department of Dermatology, Poznan University of Medical Sciences, the majority of fungal infections of the glabrous skin had a typical clinical picture allowing the children to be referred for mycological testing.

According to the literature, fungal nail infections occur in children less often than in adults and account for about $0.3 \%$ of all cases [1]. This may be due to, among other factors, faster growth of the nail plate in children compared to adults, which is associated with better blood circulation [17].

Distal and lateral subplate onychomycoses are the most common $[1,18,19]$. Gradual hyponychium keratosis leading to onycholysis takes place [9].

Superficial infections with yeast-like fungi in children occur most often in the skin folds and on the mucous membranes [15]. These places are particularly vulnerable to irritation and maceration. niewielkie zarodniki pokrywające mieszek włosowy o charakterystycznym ułożeniu (ektotriks) i powodujące łamanie włosów na poziomie kilku milimetrów ponad powierzchnią skóry. Ogniskowo może występować łagodna reakcja zapalna oraz złuszczanie skóry [4].

$\mathrm{W}$ badanej grupie wykryto także jeden przypadek zakażenia grzybem zoofilnym T. equinum, który występuje najczęściej u koni, oraz jeden przypadek zakażenia grzybem geofilnym $M$. gypseum.

Drugą pod względem częstości występowania lokalizacją zmian spowodowanych grzybami dermafitowymi była skóra gładka całego ciała. W 45\% przypadków stwierdzono zakażenie gatunkiem $M$. canis, a w 30\% T. mentagrophytes var. granulosum. Odnotowano także $3(15 \%)$ przypadki zakażenia T. verrucosum, przy czym informacje wskazywały na przeniesienie zakażenia od cieląt. Innym rzadkim grzybem był wyhodowany $\mathrm{z}$ materiału pobranego od $1 \mathrm{z}$ pacjentów antropofilny gatunek M. audouinii, podobny do M. canis, jednak różniący się od niego mikrokonidiami.

Na szczególną uwagę zasługuje przypadek rzadkiej grzybicy skóry gładkiej - zakażenie wywołane przez T. erinacei. Patogen wyhodowano z materiału pobranego z przedramienia i klatki piersiowej 14-letniej pacjentki (ryc. 6). T. erinacei jest grzybem zoofilnym, a jego naturalnym rezerwuarem są jeże, które cieszą sie ostatnio popularnością jako zwierzęta domowe. Dermatofity, które wchodzą w skład naturalnej flory niewielkich ssaków, nie wywołują u nich zmian chorobowych, co sprzyja przenoszeniu zakażenia [16]. U pacjentki na podstawie wywiadu wykluczono bezpośredni kontakt z jeżem domowym. Dokładna analiza pozwoliła jednak na ustalenie, że źródłem zakażenia była należąca do dziewczynki świnka morska. Stanowiła ona wektor zakażenia pomiędzy przebywającym w sklepie zoologicznym jeżem a pacjentką. Po upływie 3 tygodni zmiany wystąpiły również na skórze świnki morskiej.

Zakażenia skóry gładkiej wywoływane przez grzyby objawiają się zazwyczaj obrączkowymi zmianami o charakterze rumieniowym i złuszczającym, przy czym skóra w środkowej części wykwitu jest niezmieniona, a także wzniesionymi ponad powierzchnię skóry zmianami zapalnymi z możliwym zajęciem mieszków włosowych. W przebiegu niektórych zakażeń obserwuje się dodatkowo zmiany skórne w postaci grudek i strupów oraz nasilony, uporczywy świąd [1]. U dzieci badanych w Pracowni Mikologii Lekarskiej w Poznaniu większość zakażeń grzybiczych skóry gładkiej miała charakterystyczny obraz kliniczny, który uzasadniał kierowanie pacjentów na badania mykologiczne.

Według piśmiennictwa zakażenia grzybicze paznokci występują u dzieci rzadziej niż u dorosłych i stanowią ok. 0,3\% wszystkich przypadków [1]. Może to wynikać m.in. z szybszego wzrostu płytki paznokciowej u dzie- 
Sensitive children's skin exposed long term to irritant urine is susceptible to infection with yeast-like fungus. Pathogens may have an endogenous origin from the upper gastrointestinal tract of the child, but they may also be transmitted from adult carers [4]. Seven cases of yeast infection in our patients were related to glabrous skin and were found mostly in the groin and skin in the "diaper" area as well as on the face.

Interestingly, the study group children revealed nail infections, and as many as $10(58.8 \%)$ out of 17 cases concerned this location. According to the literature, Candida is the most common cause of onychomycosis in children 3-12 years of age [18] The average age of patients with nail candidiasis in the study group of children was 11 years. The youngest child was 4 years old, and the oldest was 17 years old.

The determination of the cause of the infection involved the analysis of the interview and clinical symptoms. Only 1 case coexisted with oral mucosal infection. Our study, in most cases, verified coexisting causative agents of infection, such as psoriasis, nail injury, previous antibiotic therapy, nail biting habit, staphylococcal and Pseudomonas bacteria superinfection, as well as acrylic nail application in young girls.

Mold fungi are common both in the environment and on healthy human skin. They are often found on the scalp and in interstitial spaces [20]. In healthy people, they form a natural saprophytic flora and are not an epidemiological problem. Surface infections with mold fungi are rare. Up until now, the literature has included descriptions of superinfections with mold flora of previously existing erosions, macerations, abrasions and other skin lesions [21]. Nine cases of mold infection were diagnosed in the study group. Aspergillus (3 cases) and Alternaria (2 cases) fungi were dominant, constituting the most commonly isolated mold fungi developing in the affected skin. In 4 children, the mold flora was isolated from the nail. According to the literature, this is the most common location of molds in adults [21]. However, in most cases, these are elderly patients, and the lesions affect the toes and develop in the form of "aceuliosis" induced by Scopulariopsis brevicaulis [22]. Fungal nail infection in children is rare, which is probably due to the faster growth of the nail plate and its smaller area [3]. The mold flora represents $3 \%$ of all nail pathogenic fungi [18].

In the study group, a single case of Scedosporium apiospermum was found in the material collected from the child's surgical wound following a traffic accident. Rare cases of Scedosporium apiospermum ci w porównaniu z dorosłymi, który ma związek z lepszym ukrwieniem [17].

Najpowszechniejsza jest postać dystalna i boczna podpłytkowa grzybicy paznokci $[1,18,19]$. Stopniowo następuje rogowacenie obrąbków naskórkowych paznokcia, co powoduje oddzielanie się paznokcia od łożyska (onycholizę) [9].

Grzybice powierzchowne wywołane przez grzyby drożdżopodobne u dzieci są umiejscowione najczęściej w fałdach skórnych i na błonach śluzowych [15]. Miejsca te są szczególnie narażone na podrażnienia i macerację skóry. Długotrwałe narażenie skóry dziecka na mocz, który ma właściwości podrażniające, sprzyja rozwojowi zakażeń grzybami drożdżopodobnymi. Patogeny mogą mieć pochodzenie endogenne ( $\mathrm{z}$ górnego odcinka przewodu pokarmowego dziecka) bądź przenosić się od dorosłych nosicieli [4]. Siedem przypadków zakażeń drożdżakowych u badanych pacjentów wykazano na skórze gładkiej, głównie w pachwinach oraz w obszarze „pieluszkowym”, a także na twarzy.

Co ciekawe, u dzieci z grupy badanej stwierdzono zakażenia paznokci; zmiany w tej lokalizacji wykryto w aż 10 przypadkach na 17 (58,8\%). Według piśmiennictwa najczęstszą przyczyną tej choroby u dzieci w wieku 3-12 lat jest Candida [18]. Średni wiek pacjentów z kandydozą paznokci wynosił 11 lat. Najmłodsze dziecko miało 4 lata, a najstarsze 17 lat.

Przyczynę zakażenia ustalano na podstawie wywiadu medycznego oraz objawów klinicznych. Tylko w 1 przypadku wykazano współistniejące zakażenie błony śluzowej ust. W większości przypadków badanie weryfikowało obecność współistniejących czynników sprzyjających zakażeniu, takich jak łuszczyca, uszkodzenia paznokci, stosowana wcześniej antybiotykoterapia, nawyk obgryzania paznokci, nadkażenie bakteriami Pseudomonas oraz przedłużanie paznokci techniką akrylową u dziewczynek.

Grzyby pleśniowe powszechnie zasiedlają środowisko, bytując również na zdrowej skórze ludzkiej. Często ich obecność stwierdza się na owłosionej skórze głowy oraz w przestrzeniach śródmiąższowych [20]. U osób zdrowych wchodzą w skład naturalnej flory saprofitycznej i nie stanowią zagrożenia epidemiologicznego. Zakażenia powierzchniowe grzybami pleśniowymi występują rzadko. W piśmiennictwie można znaleźć opisy nadkażeń florą pleśniową wcześniej istniejących nadżerek, maceracji, zadrapań i innych zmian skórnych [21]. W badanej grupie rozpoznano 9 przypadków zakażeń pleśniami. Przeważały grzyby z rodzaju Aspergillus (3 przypadki) i Alternaria (2 przypadki), które stanowiły większość izolowanych grzybów pleśniowych rozwijających się w obrębie zajętej skóry. U 4 dzieci florę pleśniową wyizolowano z paznokcia. Według piśmiennictwa jest to najczęstsza lokalizacja zakażeń grzybami pleśniowymi u dorosłych [21]. W większości dotyczy to jednak pacjentów w podeszłym wieku, a zmiany 
occur in extensive wounds resulting from accidents or surgery [23].

Although molds are rarely the primary cause of skin diseases, their presence may exacerbate, e.g., atopic dermatitis [2].

\section{CONCLUSIONS}

Scalp is the most common location of dermatophytic mycosis in children. There was an increase in both dermatophytic and yeast infections in children's nails. An increase in morbidity with zoonotic mycoses, related to the breeding of exotic animals, is observed. They are a potential source of new infections, which were previously not known in Poland. The increase in the incidence of mold and yeast-like fungi infections associated with dermatoses related to defects in the structure and function of the epidermal barrier, such as atopic dermatitis and psoriasis, seems to be of significant importance. The increase in fungal infections of the skin and its adnexa may be associated with an increase in the immunosuppressed population of children.

\section{CONFLICT OF INTEREST}

The authors declare no conflict of interest. pojawiają się w obrębie palców stóp, przyjmując postać "akauliozy" wywołanej przez Scopulariopsis brevicaulis [22]. Zakażenia grzybicze paznokci u dzieci występują rzadko. Przypuszcza się, że ma to związek z szybszym tempem wzrostu płytki paznokciowej oraz jej mniejszą powierzchnią niż u dorosłych [3]. Flora pleśniowa stanowi 3\% wszystkich grzybów patogennych powodujących zakażenie paznokci [18].

W badanej grupie odnotowano pojedynczy przypadek Scedosporium apiospermum. Patogen zidentyfikowano w materiale $\mathrm{z}$ rany chirurgicznej po zabiegu po wypadku komunikacyjnym. Rzadkie przypadki występowania $S$. apiospermum stwierdza się w rozległych ranach powstałych $\mathrm{w}$ wyniku wypadku lub zabiegu chirurgicznego [23].

Choć pleśnie rzadko stanowią główną przyczynę chorób skóry, ich obecność może powodować zaostrzenia np. atopowego zapalenia skóry [2].

\section{WNIOSKI}

W przebiegu grzybicy dermatofitowej u dzieci najczęściej zajęta jest skóra owłosiona głowy. U dzieci stwierdzono wzrost liczby zakażeń dermatofitowych i drożdżakowych w obrębie paznokci. Obserwuje się ponadto wzrost zachorowań na grzybice odzwierzęce w związku z hodowlą zwierząt egzotycznych. Są one potencjalnym źródłem nowych zakażeń, wcześniej nieznanych w Polsce. Wydaje się, że istotne znaczenie ma również zwiększenie częstości występowania zakażeń grzybami pleśniowymi i drożdżopodobnymi w przebiegu dermatoz związanych z nieprawidłowościami w budowie i czynności bariery naskórkowej, m.in. atopowego zapalenia skóry i łuszczycy. Nasilenie zakażeń grzybiczych skóry i jej przydatków może być związane ze wzrostem liczebności populacji dzieci z immunosupresją.

\section{KONFLIKT INTERESÓW}

Autorzy deklarują brak konfliktu interesów.

\section{References}

Piśmiennictwo

1. Lelonek E., Hryncewicz-Gwóźdź A., Baran W.: Grzybice u dzieci - co nowego? Derm Prakt 2015, 6, 50-55.

2. Adamski Z.: Epidemiologiczno-kliniczne aspekty zakażeń grzybami. Przegl Dermatol 2006, 93, 789-797.

3. Adamski Z., Hasse-Cieślińska M., Kubisiak-Rzepczyk H., Dembińska M.: Diagnostyka mikologiczna. Mikologia lekarska dla lekarzy i studentów. Z. Adamski, H. Batura-Gabryel (eds). UM, Poznań, 2007, 272-341.

4. Jain A., Jain S., Rawat S.: Emerging fungal infections among children: a review on its clinical manifestations, diagnosis, and prevention. J Pharm Bioallied Sci 2010, 2, 314-320.

5. Olszewska B., Imko-Walczuk B., Nowicki R., Dębska-Ślizień A., Wilkowska A., Rutkowski B.: Infekcje grzybicze skóry i tkanki podskórnej u chorych po transplantacji narządów. Przegl Dermatol 2016, 103, 259-272.

6. Hawkins D.M., Smidt A.C.: Superficial fungal infections in children. Pediatr Clin N Am 2014, 61, 443-455.

7. Maleszka R., Adamski Z., Szepietowski J., Baran E.: Leczenie powierzchownych zakażeń grzybiczych - rekomendacje ekspertów Sekcji Mikologicznej Polskiego Towarzystwa Dermatologicznego. Przegl Dermatol 2015, 102, 305-315. 
8. Mehrholz D., Wilkowska A., Bykowska B., Nowicki R., Barańska-Rybak W.: Drobnozarodnikowa grzybica skóry głowy opis przypadków. Dermatol Dziec 2016, 6, 83-87.

9. Maleszka R., Różewicka-Czabańska M., Ratajczak-Stefańska V.: Grzybice powierzchowne u dzieci. Stand Med Pediatr 2011, 8, 80-85.

10. Andres M., Jaworek A., Stec-Polak M., Radzimowska J., Wojas-Pelc A.: Infekcje grzybicze skóry i jej przydatków - analiza wyników badań mykologicznych Pracowni Mykologicznej w latach 2010-2014. Przegl Lek 2015, 75, 253-256.

11. Gilaberte Y., Rezusta A., Gil J., Saenz-Santamaria M.C., Coscojuela C., Navarro M.: Tinea capitis in infants in their first year of life. Br J Dermatol 2004, 151, 886-890.

12. Smith M.L.: Tinea capitis. Pediatr Ann 1996, 25, 101-105.

13. Zampella J., Kwatra S., Blanck J., Cohen B.: Tinea in tots: cases and literature review of oral antifungal treatment of tinea capitis in children under 2 years of age. J Pediatr 2017, 183, 12-18.

14. Skerlev M., Miklic P.: The changing face of Microsporum spp. infections. Clin Dermatol 2010, 28, 146-150.

15. Kuchciak-Brancewicz M., Pastuszka M., Kaszuba A.: Najczęstsze grzybice skóry u dzieci w poszczególnych okresach rozwojowych. Dermat Dziec 2011, 2, 98-106.

16. Kurtdede A., Haydardedeoglu A.E., Alihosseini H., Colakoglu E.C.: Dermatophytosis caused by Trichophyton mentagrophytes var. erinacei in a dog: a case report. Veterin Med 2014, 59, 349-351.

17. Solis-Arias M., Garcia-Romero M.: Onychomycosis in children. A review. Int J Dermatol 2017, 56, 123-130.

18. Zisova L., Chokoeva A., Sotiriou E., Valtchev V., Gospodinov D.: Onychomycosis and children - a multicenter study. Acta Med Bulg 2015, 42, 23-33.

19. Kim D.M., Suh M.K., Ha G.Y.: Onychomycosis in children: an experience of 59 cases. Ann Dermatol 2013, 25, 327-334.

20. Kurnatowska A.: Wybrane zagadnienia mikologii medycznej. Promedi, Łódź 1995.

21. Trzmiel D., Lis-Święty A., Bergler-Czop B.: Klinika zakażeń grzybiczych skóry i jej przydatków w praktyce lekarza rodzinnego - problem ciągle aktualny. Med Og Nauk Zdr 2011, 17, 212-217.

22. Maleszka R., Ratajczak-Stefańska V., Różewicka-Czabańska M.: Zmiany infekcyjne paznokci. Przegl Dermatol 2011, 98, $120-127$.

23. Cortez K.J., Roilides E., Quiroz-Telles F.: Infections caused by Scedosporium spp. Clin Microbiol Rev 2008, 21, $157-197$.

Received: 8.06 .2017

Accepted: 17.07.2017

Otrzymano: 8.06.2017 r.

Zaakceptowano: 17.07.2017 r.

How to cite this article

Browicz A., Kubisiak-Rzepczyk H., Hasse-Cieślińska M., Karasińska A., Adamski Z.: Analysis of superficial mycoses in children examined in 2013-2016 in the Unit of Medical Mycology at the Department of Dermatology, Poznan University of Medical Sciences. Dermatol Rev/Przegl Dermatol 2017, 104, 411-422. DOI: https://doi.org/10.5114/dr.2017.69948. 